descriptions of ores, and Kirkaldy's tests of the mechanical properties of the iron; but it should be understood that these tests were taken with a view rather to test various modes of manufacture than to show high results. Only a small proportion of the samples had been subjected to the refinery process, and the variable percentage of phosphorus may be taken really as indicative of the extent to which the cinder had been removed from the metal.

Another table gives the analysis of slags produced in the process. These are, no doubt, rich in iron, but it must be remembered that in the case of comparatively pure ore they can be used almost entirely in succeeding cliarges, and that in the case of ores containing much sulphur and phosphorus they are the recipients of those impurities--in the same way as the puddling cinder carries off the same impurities in the puddling furnaceand thus serve a usefnl end.

If rich cres, such as hematites, are available, it is more advantageous to use a stationary furnace and to modify the process as follows:-

A mixture of pulverulent ore mixed with a suitable proportion of fluxing materials and reducirg agent is prepared, and from four to five ions of it is charged from a charging platform into the heated chamber to the depth of some tweive to fifteen inches. But before charging the mixtura some coke dust or anthracite powder is sprear over the bottom and sides of the chamber to protect the silica lining of the same. The heat of the furnace is thereupon raised to a full welding heat, care being taken that the flane is as little oxidising as possible. The result is a powerful superficial action upon the rixture or batch, causing simultaneous rediclion of the ore and fusion of the earthy constituents. In the course of two hours a thick skin of malleable iron is formed all cver the surface of the mixture, which, on being withdrawn by means of hooks, is consoliclated and cleared of cinder under a hammer, and rolled out in the same heat into rough sheets or bars, to be cut up and finished in the refinery furnace or charcoal hearth. One skin being removes, the furnace is closed again, and in the course of an hour and a half another skin is formed, which, in its turn, is removed and shingled, and so on until, after three or four removals. the furnace charge is nearly exhausred. A fresh charge is then added, and the same operation continued. Once every twelve hours the furnace should, however, be cleared entirely, and the furnace lining be repaired all round.

The shingled metal so produced forms an excelient melting materal for the open-hearth or Siemens-Martin process; but if ores both rich and free from sulphur and phosphorus are used, together with xoll and hammer scale, which forms an admirable admixture, I simplify the process still further in causing the fusion to take place in the reducing furnace.

The furnace having been charged with say five tons of batch, the heat is allowed to ply on it for four or five hours, when about two tons of hematire pig iron are charged upon the surface by preference in a heated condition. The pig metal on meltiry constitutes a bath on the surface of the thick metallic skin previously formed, and gradually dissolves it on the surface whive it is forming afresh below, and in the course of from three to four hours the whote of the materials charged are rendered fluid, consisting of a meiallic bath with a small percentage of carbon, covered with a glassy slag containing about 15 per cent. only of metallic iron. The carbon of the bath is thereupon brought down to the desired point of only about I per cent. of carbon and spiegeleisen or ferro-manganese is added, and the metal tapped in the nsual manner. By these means the direct process of making cast steel is carried to a further limit than I have heen able to accomplish before, and no difficulty has presented itself in carrying it into effect. The steel so produced is equal in qualiiy to that produced by the open hearth process as now practised. It light scrap, such as iron and steel turnings or sheerings, are available, these may be mixed with advantage with the batch to increase the rield of metal.

These are, in short, the more recent improvements in the direct process of producing iron and steel which $I$ have been able to effect, and which I should have been glad to lay before the Iron and Steel Institute in a more complete form than I am able to do at the present time.

\section{THE AMERICAN ASSOCIATION AT} NASHVILLE

$A S$ we have said already, while the Nashville Mecting of the American Association could not be called a brilliant one, most of the papers read were of substantial importance, and show that a large amount of valuable scientific work is being carried on in the United States. The number of visitors does not appear to have been up to the usual mark, mainly, we believe, on account of the great heat which prevailed at Nashville, but among those present were many of the most prominent men of science in America. The reception by the authorities of the State and city was all that could be desired, and the arrangements as to excursions, entertainments, and public lectures were in every way satisfactory.

The Western Union Telegraph Company, which has a Telegraphic Station in the building where the Association met, terdered the use of its wires free for all members so far as related to domestic affairs.

It is customary at the meetings of the American Association for each of the vice-presidents to give a public lecture; we give a long abstract of the lecture by Prof. O. C. Marsh, the importance of which cannot be overrated. We have already referred briefly to Prof. Pickering's paper on the Endowment of Research. The first obstacle encountered, he said, was the opinion widely maintained, even by scientific men, that the original research of a country was natural, and that it was useless to try to force it. We might as well say that music and art were natural growths. What should we have of ancient art were it not for the encouragement of many ancient rulers? In later dass how would art and literature have thrived had it not been for the support of the public in purchasing books, \&c. With the man of science it was different. There was generally little or no pecuniary reward for his success. The consequence was he was obliged to engage in some other occupation, generally teaching, which still allowed a little time for research. If these same men were allowed to devote their entire energies to investigation, and were rided by the necessary appliances, far more would be accomplished. The solution of the matter was organisation, the carrying out of a plan by which researches should te reridered as systematic as the process of mechanical arts. They had first tine munificent bequest of one of the first presidents of the Assuciation. The inc me of the Baclie fund amounted to 2,000 dols, or 3,000 dols. Second was the Rumford fund, originally intended for giving medals in light and heat, but now largely applied to aiding investigation in these sciences, Besides these were many indirect aids. The paper then gave a plan of an in titution for making researches : First, a president; second, a corps of investigators of acknowledged scientific ability; third, a large corps of assistants, whose duty it should be to carry out work laid out for them ; fourth, workmen, such as mechanics. He then went on to describe a building such as would be as perf ct as possible for the institution. It was useless to hope for architectural beauty, as the effect would be spoiled by attachments made to the exterior. No more common mistake was made than in wasting money which should be used for equipment. They had too many colleges with far too little endowment. Such an institiztion, added to a college, would prove of great advaritage.

At a gentral evening meeting, Prof. Newcomb (president) spoke at some length, extemporaneously, on the two recent important discoveries made by American men of science, viz., the existence of oxygen in the sun, by Prof. Draper, and the satellites of Mars, by Prof. Hall. At the same evening meeting Prof. A. R. Grote, of Buffalo, read a sketch of a scheme for an international scientific service formed by the union of the various civilised governments and national scientific societies, for the carrying out of such scientific work as all the world is interested in. Under the auspices of such an association "all extra-limital, astronomical, geographical, and biological expeditions would be fitted out and dirested to those places which would be most fruitful for the particular purpose."

Of the papers read in the various sections we are able, at present, to give little else but the titles. In Section A, which includes Mathematics, Astronomy, Physics, Chemistry, and Mineralogy, the following, among other papers were read:On a New Type of Steam Engine theoreticaliy capable of utilising the full Mechanical Equivaient of Heat Energy, and on some points of Theory indicating its Practicability, by Prof. R. H. Thurston; Mechanics of the Flight of Birds, by Mr. A. C. Campbell. An interesting paptr in this section by Prof. Forshey, treated of The Physics of the Gulf of Mexico and of its Principal Affluent the Mississippi; the author brought together many important data concerning what he styled "the cis-Atlantic Mediterrancan." Another paper in (this section by P'rof. Mendenhall, was On Measurement of the Wave-length of the Blue Line of the Indium Spectrum. 
A mong papers in Section B (Geology, Zoolngy, Botany, and Anthropology! we notice the following as likely to prove of importance:--The Struchure of Enuptive Mountains, by Prof. Powell; On Sex in Flowers, by Mr. Thos. Meehan; On the Orizinal Conniction of the Eastern and Western Coalfields of the Ohio Valley, On the Continutation of the Fields of the Alleghany Chain to the North of the Delaware River, and On the Geosraphical and Geological Distribution of the Gemus Biatricea, and of certuin other Fossil Corals in the Rocks of the Cincinnati Group, all by Prof. Shaler; On the Classification of the Extinct Fishes of the Lotwer Types, and On the Origin of Structural Variation, by Prof. Cope; Notes on the Geolooy of the Rocky Mountains, by Prof. Sterry Hunt; Some Potular Errors conconing the North American Indians, by Capt. Powell. In a paper by the same author, On Overplacement, he asserted that the effects of glacial action hacl been greatly over-estimated in the western country, and that the "overplacement" in the Mississippi Valley was due rather to the erosion of the atmosphere, the rains of centuries, and the rivers. A curious paner in this section was by a lady, Mrs. H. K. Ingram, On Atmospheric Concussion as a Means of Disinfection, in which she confidently advanced the idea, based on the germ-theory of clisesse, that by means of concussion produced by gunpowder explosion or other effective method, cholera and other epidemic diseases could be effectually prevented or dissipated. In a paper by Lieut. -Col. Mallery, the author held that the Indians are not passing away; there are now in existence, he stated, 300,000 Indians, of whom 50,000 are Sisux. Instead of decreasing with advancing civilisation, they are steadily increasing, and Col. Mallery believes that the native population of America, noith of Mexico, at the time of its discovery, has been widely over-estimated. Capt. Powell agreed with Col. Mallery, and stated his conviction that at the time of the discovery of America there were not more than 500,000 natives north of Mexico, while now in the Statss, Canada, and Alaska there are about 400,000. As president of the Sub.section of Anthropology, Prof. Domiel Wilson gave an interesting address on l'aces in America, presenting a résumé of the various theories that had been advanced with respect to American ethmology and the peopling of America, and giving some wise advice as to how future researches ought to be conducted. Another anthropological paper was on the Origin of the Fatanese, by a native of Tokio, Shuje Isawa, in which the author canse to the conclusion that the present Japanese are descerded from Hindoo conquerors.

No paper of general importance seems to have been read in permanent Sub-section C (Chemistry), all of them, judying from the titles, being on points mainly of manufacturinis interest.

It was decided that the next meeting should be held at St. Louis, and at the closing meeting an Education Committee was appointed with a view to the introduction of science into the schools of the country. Another committee was appointed to report annually on the relations of science to the industrial arts, and the following important resolution was passed in reference to the Signal Service Weather Reports :-

"Resolved, that this Association most respectfully asks the attention of Congress and the country to the great advances in the science of meteorology and in the art of weather prediction, which might be hoped for if the meteorological observations now taken by the Army Signal Office, under the direction of the Secretary of War, were made the subject of special research and discussion by scientific experts.

"Resolved, further, that a committee of five members or fellows be appointed by the Presiclent to represent this Association before Congress as petitioners for such permanent and liberal organisation of the meteorological service, that the valuable material collected by it may be utilised in the manner here suggested."

\section{INTRODUCTION AND SUCCESSTON OF VERTEBRATE LIFE IN AMERICA ${ }^{1}$}

Ir.

THE reptiles most characteristic of our American cretaceous strata are the Mosisauria, a group with very few representatives in other parts of the world. In our cretaceous seas

I Abstract of a lecture delivered at the Nashville meeting of the American Association, August 30, by Prof. O. C. Marsh Continued from p. 450. they ruled supreme, as their numbers, size, and carnivorous habits enabled them to easily vanquish all rivals. Some were at least sixty feet in length, and the smallest ten or twelve. In the inland cretaceous sea, from which the Rocky Mountains were beginning to emerge, these ancient "sea serpents" abounded; and many were entombed in its muddy bottom. On one occasion, as I rode through a valley washed out of this old ocean bed, I saw no less than seven different skeletons of these monsters in sight at once. The mosasaurs were essentially swimming lizards, with four well-developed paddles, and they had little affinity with modern serpents, to which they have been compared.

The Crocodilic are abundant in rocks of cretaceous age in America, and two distinct types are represented. The tertiary marine beds of the Atlantic coast contain comparatively few crocodilian remains, and all are of modern types, the genus Gavialis having one eocene species, and the alligator being represented only in the late:t deposits.

It is worlhy of special mention in this connection that no true Lacertilia, or lizards, and no Opliadia, or serpents, have yet been detectrd in American cretaceons bets; although their remains, if present, would hardly have escaped observation in the regions explored. The former will doubtless be found, as several species occur in the mesozoic of Europe, and perhaps the latter, although the ophidians are apparently a more modern type. In the encere lake-basins of Western America, remains of lizards are very numerous, and indicate species much larger than any existing to-day.

The first American serpents, so far as now known, appear in the eocene, which contrins also the oldest European species.

The Pterosizuria, or flying lizards, are among the most interesting reptiles of mesozoic time, and many of them left their remains in the soft sediments of our inland cretaceous sea. These were veritable dragons, having a spread of wings of from ten to twinty-five feet.

The strange reptiles known as Dinosantia, which, as we have seen, were numerous during the deposition of our triassic shales and sanditones, have not yet been found in American Jurassic, but were well represented here throughout the cretaceous, and at its close became extinct. These animals possess a peculiar interest to the anatomist, since, although reptilian in all their main characters, they show clear affinities with the birds, and have some features which may point to mammals. The cretaceous dinosaurs were all of large size, and most of them walked on the hind feet alone, like modern struthious birds. Near the base of our cretacesus formation in beds which I regard as the equivalent of the European Wealden, the most gigantic forms of this order yet discovered have recently been brought to light One of these monsters (Tiranosaurus montanus) from Colorado, is by far the largest land animal yet discovered, its dimensions being greater than was supposed possible in an an mal that lived and moved upon the lind. It was some fifty or sixty feet in length, and, when erect, at least thirty feet in height. It doubriess fed uron the foliage of the mountain forests, portions of which are preserved with its remains. With Tilanosaurus the bones of smaller dinosaurs, one (Nanosaurus) not larger th:n a cat, as well as those of crocodiles and turtles, are not uncommon. The recent discovery of these interesting remains, many and various, in strata that had long been pronounced by pro fessional explorers barren of vertebrate fossils, should teach caution to those who decline to accept the imperfection of our krowledge to-day as a fair plea for the supposed absence of intermediate forms.

In the marine crelaceous beds of the west only a single dinosaur (Hadrosaurus agilis) has been found, but in the higher fresh-water beds which mark the close of this formation their remains are numerous, and indicate several well-marked species, if not genera.

The first appearance of birds in America, according to our present knowledge, was duing the cretaccous period, although many announcements have been made of their existerice in preceding epochs. The evidence of their presence in the trias, based on footprints and other impressions is at present, as we have seen, without value, although we may confidently await their discovery there if not in older formations. Archcropteryx, from the European Jura, the oldest bird known, and now fortunately represented by more than a single specimen, clearly indicates a much higher antiquity for the class. The earliest American forms at present known are the Odontornithes, or birds with teeth, which have been exhumed within the last few years 